\title{
パルスレーザ及び熱画像を利用した 干潟地形観測手法 \\ THE OBSERVATION METHODS USING PULSE-LASER AND THERMO-GRAPHY ON THE GEOGRAPHICAL FEATHER OF THE TIDAL FLAT
}

\author{
中島秀雄 ${ }^{1} \cdot$ 米原吉彦 $^{2} \cdot$ 清水勝義 $^{3}$ ，石田辰英 ${ }^{4}$. 徳永企世志 ${ }^{5}$ \\ Hideo NAKAJIMA, Yoshihiko YONEHARA, Katsuyoshi SHIMIZU, \\ Nobuhide ISHIDA, and Kiyoshi TOKUNAGA
}

\begin{abstract}
1 国際航業侏国土マネジメント事業本部水域環境部( (191-0065 東京都日野市旭が丘 3-6-1) 2 国土交通省中国地方整備局広島港湾空港技術調查事務所環境課長（テ730-0029 広島県広島市中区三川町 2-10） 3 国土交通省中国地方整備局広島港湾空港技術調查事務所長（干730-0029 広島県広島市中区三川町 2-10） 4 正会員 国際航業侏新事業開発本部シビルコンサルタント部(テ102-0083 東京都千代田区教町 3-2) 3 国際航業㑣総合技術部海洋調查グループ( T812-0013 福岡県福岡市博多区博多駅東 3-6-3)
\end{abstract}

In order to observe the geographical features conveniently, as a information of the tidal flat formation, we conducted the observation using Pulse-laser and Thermo-graphy at Yuzaki-Higata tidal flat at Mizushima port, Okayama prefecture. As a result of this observation, we concluded following matters:-

1) Geographical features at the area covered by the water, we could not observe the geographic features by Pulse-laser. However, at the other area, using Pulse-laser, we could obtain the geographical features more effectively than using the other existing methods.

2) Using Thermo-graphy, we could observe the location of the tidal flat and bird's flying even in the dark.

Key Words : geographical features, tidal flat, Pulse-laser, Thermo-graphy

\section{1. まえがき}

干潟は,潮汐によって干出と水没を繰り返す勾配 の緩い沿岸域であり,多種多様な生物・生態系が生息 しており,水質浄化機能,生物生産機能,親水機能など, 多くの役割を果たしている.国土交通省では,干潟の ような貴重な自然環境を積極的に保全·創造する取 り組みを進めている.しかし,期待する機能を十分に 発揮する干潟を創造するための技術には,まだ研究 の余地が残されている.特に干潟の地形変化を的確 に予測することは難しく,モニタリングを行い,その 変化特性を把握するなど,様子を見ながら適宜対応 することが必要である.しかし，地形に関するデータ 取得は観測員が直接干潟上を移動しながら実施して おり,多大の時間と費用を費やしているのが現状で ある.そこで,本研究では干潟の形成基盤となる地形 を容易に観測するため,パルスレーザ及び熱画像を 利用した観測手法の有効性について考察を行う。

\section{2. 研究の内容}

本研究は, 国土交通省中国地方整備局宇野港湾工
事事務所により岡山県水島港勇崎干潟 (図-1)を対 象として実施された地形測量と合わせて, 2001 年 11 月 $16 \sim 17$ 日及び 2002 年 3 月 2 日の大潮期最干時に パルスレーザ及び熱画像利用による観測を実施した ものである。

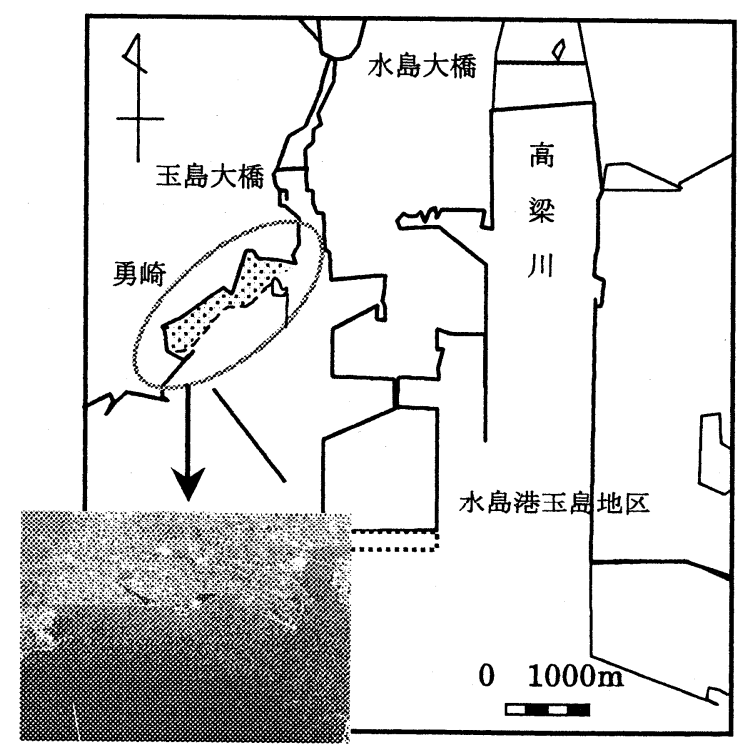

図-1.調査対象エリア 
勇崎干潟は, 砂砅, 泥砂で構成された前浜干潟であ り, 後背地にはコンクリート突堤, 石積突堤が, 潮間 帯には根固石, 澪が存在する. 観測に用いた機器は, 港湾設計・測量・調査等業務共通仕様書 ${ }^{1)}$ の精度基 淮を満たした光波測距儀（以下,TS とする）及び比 較対照機器として選定したパルスレーザを光源とす るノンプリズムトータルステーション（以下, NPTS とする), パルスレーザにより対象物をスキャン測距 する 3D スキャン（以下, 3D とする）である.これら の機器を用いて, 干潟近傍の地点にて観測を行い, 干 潟地形の観測可能距離, 精度について比較検討した. また, 赤外線熱画像装置（以下, 熱ビデオとする）を 用いて地表面（水面）の温度を観測することによっ て干潟の特性について熱画像解析を行った (表-1).

表-1.各調查手法の概要

\begin{tabular}{|c|c|c|}
\hline 使用機器 & 観測距離 & 精 度 \\
\hline $\begin{array}{c}\text { T S } \\
\left(10^{\prime \prime} \text { 読み) }\right.\end{array}$ & $7 \sim 1,000 \mathrm{~m}$ & $\begin{array}{l}\text { 距離土15mm } \\
\text { 角度 } 10^{\prime \prime}\end{array}$ \\
\hline $\begin{array}{l}\text { N P T S } \\
\text { (INT5000) }\end{array}$ & $5 \sim 1,000 \mathrm{~m}$ & $\pm 20 \sim 50 \mathrm{~mm}$ \\
\hline $\begin{array}{l}\text { 3DV-ザースキキけ } \\
\text { (LMS-Z210) }\end{array}$ & $2 \sim 350 \mathrm{~m}$ & $\pm 25 \mathrm{~mm}$ \\
\hline $\begin{array}{c}\text { 熱ビデオ } \\
\text { (赤外線熱画像装置) }\end{array}$ & $\begin{array}{c}\text { 距離: } 30 \mathrm{~cm} \sim \infty \\
\text { 温度: }-20 \sim 300^{\circ} \mathrm{C}\end{array}$ & - \\
\hline
\end{tabular}

ここで,TS は地盤高を直接水準測量するレベル測 量とは異なり,距離と角度から 2 点間の高低差を以 下の式で間接的に求める方法である(図-2).

$$
\mathrm{H}_{\mathrm{B}}=\mathrm{H}_{\mathrm{A}}+\mathrm{h}+(\mathrm{S} \times \sin \theta)
$$

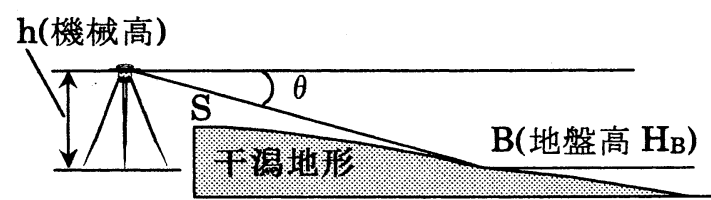

$\mathrm{A}$ (地盤高 $\mathrm{H}_{\mathrm{A}}$ )

\section{図-2.間接水準測量}

TS によってこれまでの直接水準測量と同様に手 軽に観測を行えるようになったが,この観測には大 気の屈折,地球の形状から距離に応じて無視できな い誤差が含まれる.TSには一般にこの誤差を補正す る機能が設けられている.そのほか,角度誤差により 水準測量結果に誤差を生じる.本研究で使用した 10” の角度誤差をもつTSでは,各測量距離に応じて 表-2 に示す距離誤差が生じることとなる.

したがって,TSを使用する場合には,直接水準測量 よりやや精度が劣ることを踏まえて,観測すること が重要である.本研究では,干潟という潮位の影響な どを受け,常に変化している場所を対象としている ことから,この誤差は大きくはないと判断した.
表-2.観測距離毎の水準誤差

\begin{tabular}{|c|c|c|c|}
\hline $\begin{array}{c}\text { 観測距離 } \\
\text { 角度誤差 }\end{array}$ & $50 \mathrm{~m}$ & $100 \mathrm{~m}$ & $150 \mathrm{~m}$ \\
\hline $10^{\prime \prime}$ & $2.42 \mathrm{~mm}$ & $4.85 \mathrm{~mm}$ & $7.27 \mathrm{~mm}$ \\
\hline
\end{tabular}

\section{3. パルスレーザによる干潟観測}

パルスレーザを用いた NPTS,3D はレーザの特性 から水分の残った干潟部では反射率が弱く,地盤高 を実測することが困難であった.そのため観測可能 距離は NPTS が約 $1,000 \mathrm{~m}, 3 \mathrm{D}$ が約 $350 \mathrm{~m}$ を確保し ているが,今回の観測時に確実にデータを取得でき たのは干潟が干出した $200 \mathrm{~m}$ 程度までであった.ま た,それより短い距離でも,水分の残った部分につい ては欠測となった.そこで NPTS では実測データか ら TIN モデルを発生させ(図-3),周辺の実測データ 3 点から計算することによって欠測データを補完した. また 3D では半径 $1 \mathrm{~m}$ 以内のデータを平均して,任意 の地点の地盤高とした.

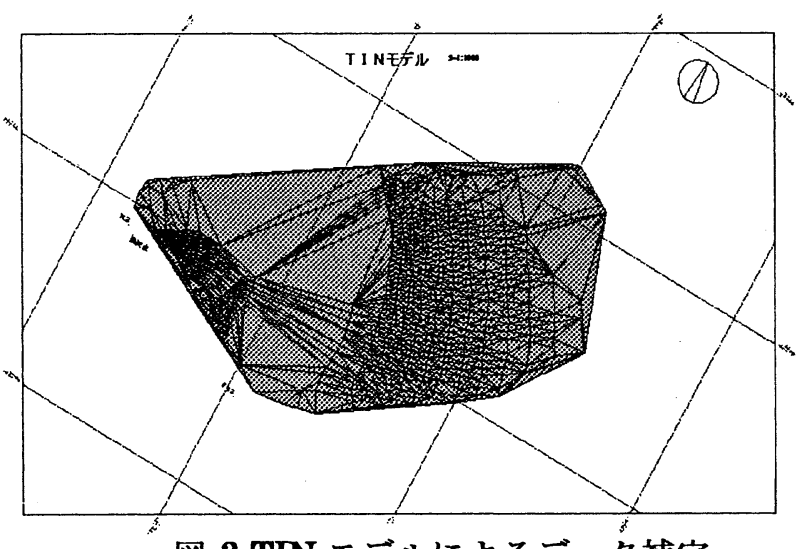

図-3.TIN モデルによるデータ補完

このようにして,取得したデータと TS で実測した データから断面図を作成して比較した(図-4).

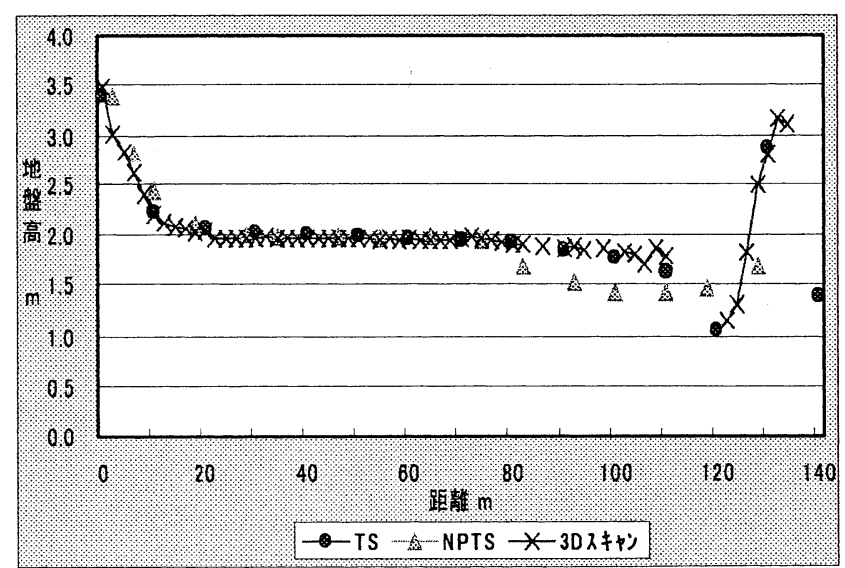

図-4.比較断面図 
その結果,TS と NPTS,3D 各々の相関係数は 0.92,0.99 と高い值であった.また,欠測がほとんどな く観測できた $0 \sim 80 \mathrm{~m}$ 地点までのの観測誤差は NPTS が $\pm 20 \mathrm{~cm}, 3 \mathrm{D}$ が $\pm 10 \mathrm{~cm}$ 以内であった(表-3).

表-3.TS と NPTS,3D データの誤差

\begin{tabular}{|c|c|c|}
\hline 観測距離 & NPTS & $3 \mathrm{D}$ \\
\hline $0 \mathrm{~m} \sim 80 \mathrm{~m}$ & $-7 \mathrm{~cm} \sim+20 \mathrm{~cm}$ & $-10 \mathrm{~cm} \sim+4 \mathrm{~cm}$ \\
\hline $80 \mathrm{~m} \sim 140 \mathrm{~m}$ & $-64 \mathrm{~cm} \sim+35 \mathrm{~cm}$ & $-16 \mathrm{~cm} \sim+6 \mathrm{~cm}$ \\
\hline $0 \sim 140 \mathrm{~m}$ & $-64 \mathrm{~cm} \sim+35 \mathrm{~cm}$ & $-16 \mathrm{~cm} \sim+6 \mathrm{~cm}$ \\
\hline
\end{tabular}

また,高所作業車を利用して,観測地点を約 $13 \mathrm{~m}$ 高 くして観測を行った結果,NPTS で約 $500 \mathrm{~m}$ まで,3D で約 $150 \mathrm{~m}$ まで観測可能距離が延びた.これは,観測 地点を高くすることによって,干潟へのレーザの入 射角が哚くなり反射パルスが大きくなったためと考 えられる.水分が残った部分では欠測してしまうと いう課題はあるが,ノンプリズムで観測が可能なこ とから干潟部へ人が入ることなく観測できることは 有意義といえる.

\section{4. 熱画像による干潟観測}

パルスレーザによる干潟観測では,水分が残って いる部分の観測が難しいことから,熱画像を取得す ることにより水際線観測の補完,鳥類飛来状況の把 握,また潮位と熱画像干潟地盤高の観測について検 討した.

\section{（1）写真と熱画像との比較}

熱ビデオと写真により干潟を観測した結果を比較 した(図-5,6). 写真で確認することができる干潟部,海 域,干潟に飛来した鳥など,熱の差があるものについ ては,熱画像によっても把握することができた.

また,写真では判別の難しい干潟干出部の水分残 留状況についても,その温度差から,判別することが 可能であった.

さらに日没後,暗くなると,肉眼,写真では確認する ことができない水際線の位置,干潟へ飛来する鳥類 についても熱画像では観測することが可能である. しかしながら,暗くなってから干潟部を観測する際 には,観測者の肉眼では確認することが困難である ことから,明るいうちに観測ポイントを設定して機 器を取り付けておくとともに,明るい時にも熱ビデ 才観測を実施し,熱画像として観測されるであろう 対象物についてのデータを取得しておき,より正確 なデータ解析ができるようにすることが必要とな る.

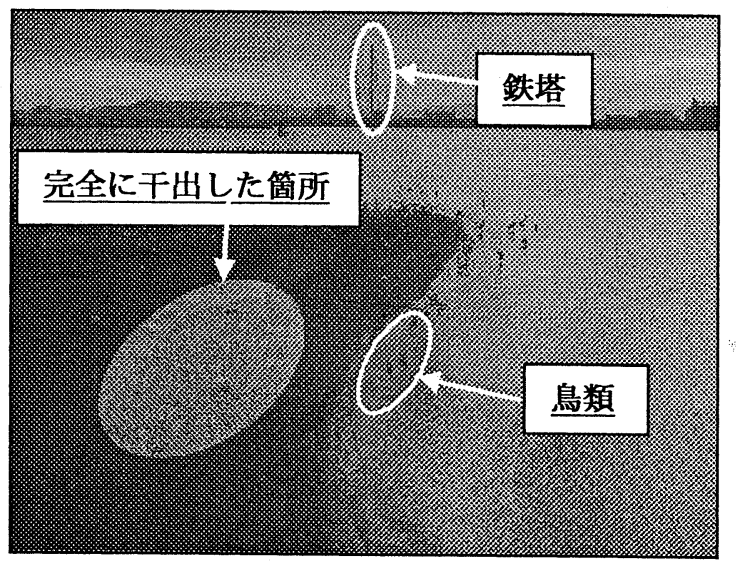

図-5.写真からの解析

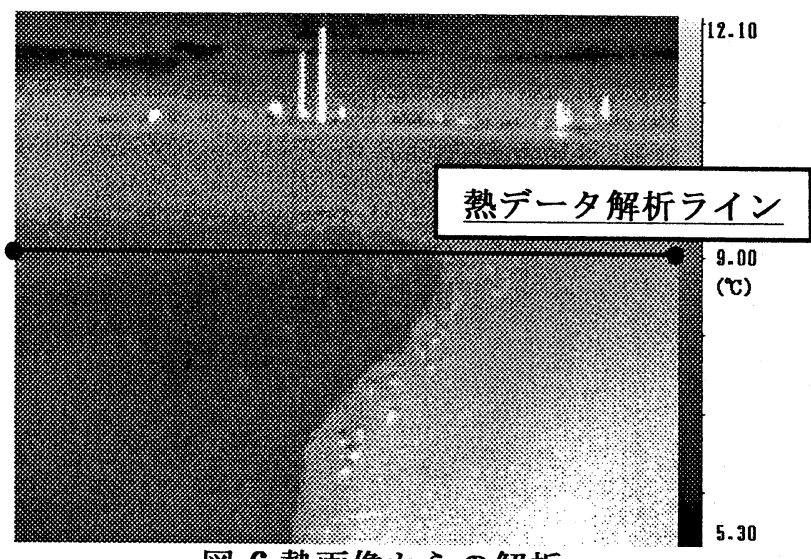

図-6.熱画像からの解析

図-6に引いたライン上の熱データをグラフ化す ると,干潟干出部と水面の境界で急激に温度が変化 しており(図-7),水際線近傍の干出部と水面では,約 $3^{\circ} \mathrm{C}$ 差があることが判る.また干出部においても水 分が残っている部分は,完全に干出している部分よ りもやや温度が高い(約 $\left.1^{\circ} \mathrm{C}\right)$ ことが読み取れる。

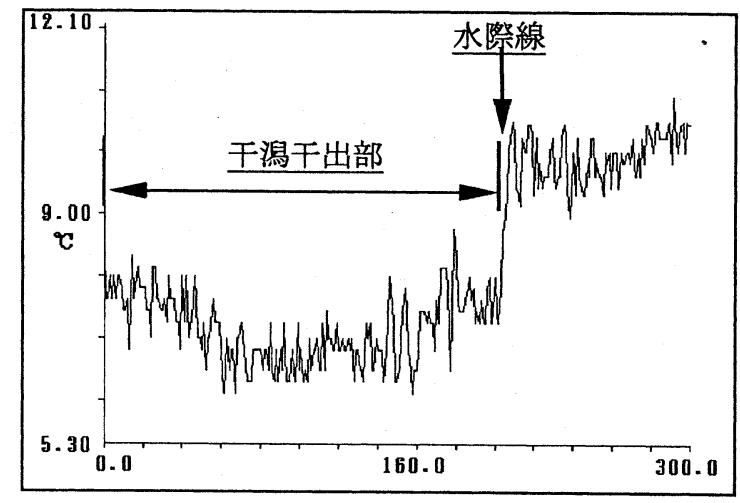

図-7.干潟の温度変化

このように同じ干潟干出部でも水際線の内側でも 表面の温度がやや異なることから,そこに生息する 生物・生態系の種類,地盤環境が異なることが想定さ れる. 


\section{（2）写真と熱画像による干潟の連続観測}

平成 14 年 3 月 2 日の大潮期に,干潟の連続観測を 行った.観測は干潟背後の高所(標高約 $40 \mathrm{~m}$ )からデ ジタルカメラと熱ビデオにより,7:30〜11:00 及び 16:30〜20:30にかけて 30 分毎にデータを取得した. 取得したデータは観測地点 1 点からの観測であるた め,地形に依存して幾何学的に歪んで観测している (中心投影).この地形による歪みを解消するには,地 表を投影面に対して垂直に投影(正射投影)する必要 がある2)。

そこで画像解析ソフトを利用し,正射投影データ である国土地理院発行の数值地図と重ね合わせるこ とによって,現地で取得した写真及び熱画像データ を正射投影した(図-8).

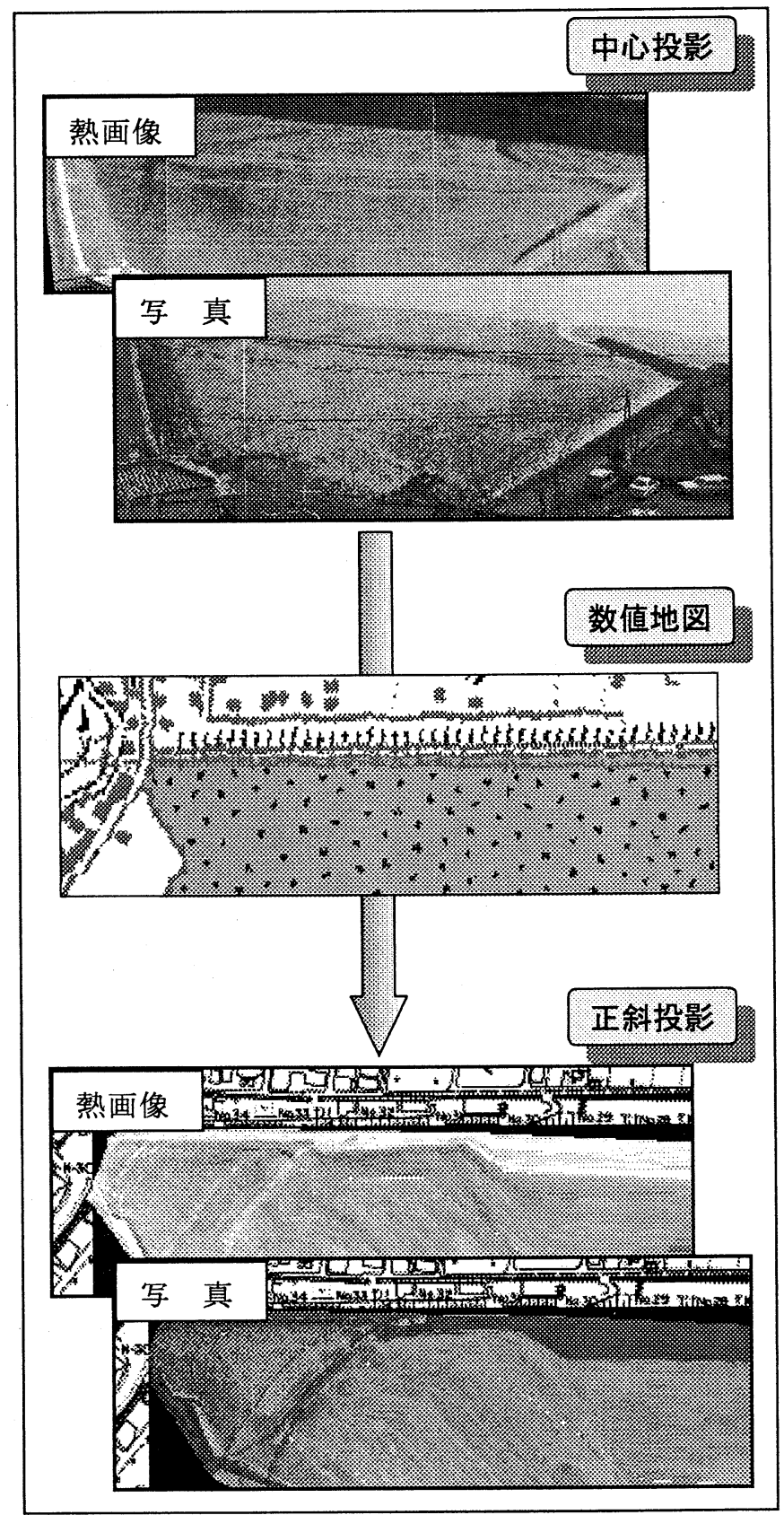

図-8.観測データの正射投影化
日没後,夜間は写真では水際線を確認することは 不可能であるが,熱画像データによると水域と陸域 との境界を熱データの違いとして観測することがで きる.しかし,干出後もしばらくの間は水域と陸域の 温度にあまり差がみられない場合がある(図-9).これ は干潟が干出してもいくらか水分が残っていること, また干出部がすぐには温度が下がらないことなどが 影響していると考えられるが,その際は写真により 判別する必要がある.このようなことから,水際線を 昼間,夜間を問わずに連続して観測するためには,写 真と熱画像両方による観測が望ましいと言える.
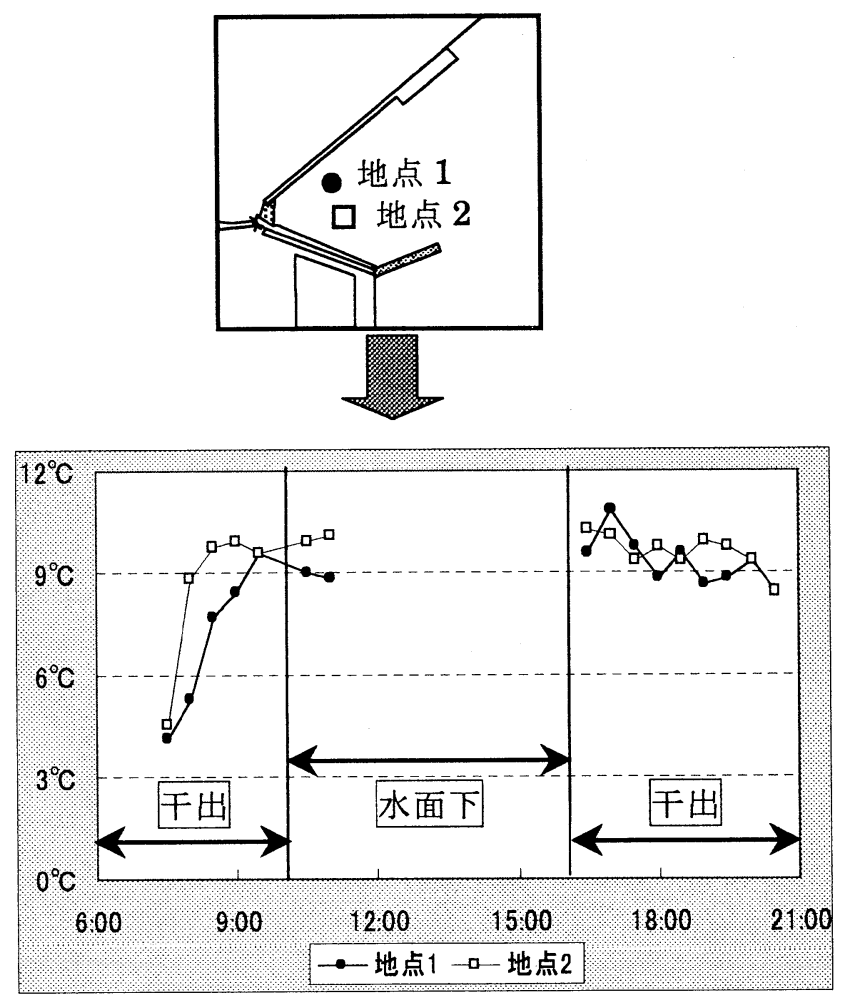

図-9.観测地点別の熱データ

今回の観測地点は干潟背後の高所から観測したこ とにより，正射投影化の作業が非常に困難であった。 正射投影する際には数值地図との標定点が必要とな るが,元来,干潟部は平坦な砂泥質のため,標定となる 点が十分ではなかった.そこで,周辺の護岸の端部な どを標定点としたが,観測地点があまり高くなかつ たため,干潟に対して傾斜角度が浅く十分に正射投 影化ができなかった.しかしながら, 潮の満ち引きに 伴い常に移動している水際線の位置を概略的に把握 することはできた.

このようにして,写真と熱画像から解析した水際 線の変化を図-10に示す. 


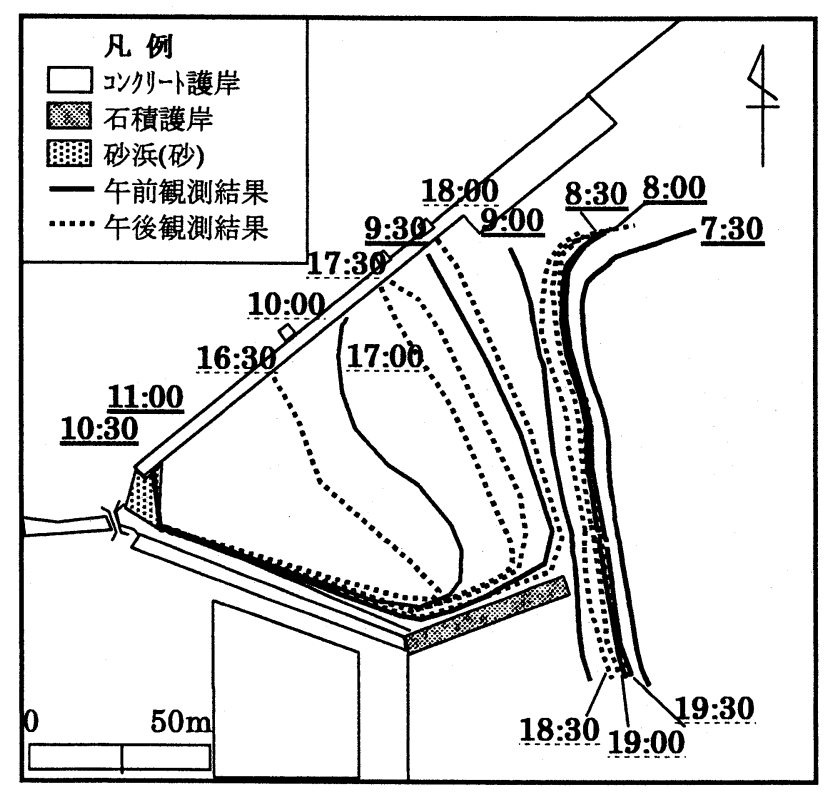

図-10.水際線の経時変化

水際線は護岸に近いほど,移動量が大きくなる.こ れは護岸に近いほど,干潟の勾配が緩やかなことに よる.また,標定点の設置,数值地図との重ね合わせに よって,水際線の座標を求めることも可能である.

（3）TS と熱画像, 潮位による水際線の比較

調査対象エリアに最も近い玉島検潮所における観 測日の潮位は, 図-11 のとおりであった.この潮位は, 水際線上の地盤高と見なすことができる.

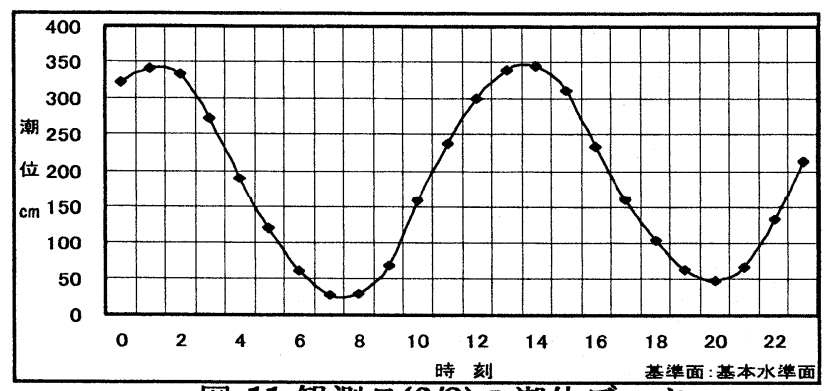

図-11.観测日(3/2)の潮位データ

ここで, TS により実測した地盤高データより解析 した等高線図とその地盤高值 $(\mathrm{DL}$ 上 $150 \mathrm{~cm})$ に相当す る潮位時刻を図-11 から求めると, 9:50, 17:10 とな る.その時刻に最も近い熱画像データは 10:00,17:00である.そこで, TSによる観測結果から 求めた地形勾配, 約 1/200 から 10 分間 $(10: 00 \rightarrow$ $9: 50,17: 00 \rightarrow 17: 10)$ の潮位変化分を考慮し, 熱画像 より求めた水際線を移動させた結果を示す（図 $-12)$.

TS と熱画像, 潮位より求めた DL 上 $150 \mathrm{~cm}$ 等高線は やや異なるが，これは俯角約 $40^{\circ}$ で観測した熱画像 データによる正斜投影の誤差によると考えられる.

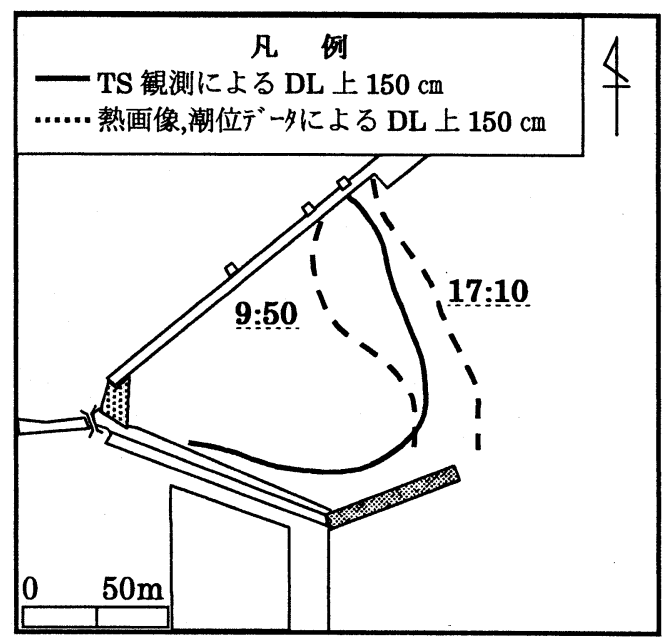

図-12.TS と熱画像,潮位より求めた水際線の比較

\section{6. 今後の課題}

本研究では,パルスレーザと熱画像を利用した干 潟地形観測についてその有効性を考察した. その結 果, パルスレーザ, 熱画像ともにこれまでの干潟地形 観測よりも,観測員の削減されるなど作業の効率化 が見込まれる.しかし, 水分が残っている部分では, レーザの特性上, 欠測となりやすく, 今後の課題とし て挙げられる. また, 干潟に対して,より垂直に近く, より高い場所からの観測の方がレーザの反射パルス が大きくなり観測精度も良くなる.そこで, 干潟の傾 斜に向かう方向 (海側)に観測地点を設置することが 望ましいと考えられる(図-13).

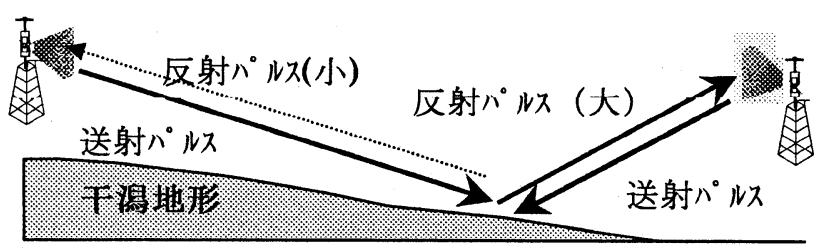

図-13.レーザの送射方向

水際線の観測については,熱画像を利用すること で,夜間でも水際線の位置を把握することが可能で あることが判った.しかし、その位置をより正確に観 測するためには,できるだけ正射に近い角度から観 測するとともに,位置特定のための標定点を設置す る必要がある.また,データ取得,転送をリモートコン トロールすれば,自動観测も可能である.

干潟の保全·創出をより一層,促進するためにも， 今後の更なる研究が重要である.

\section{参考文献}

1) 国土交通省港湾局:港湾設計 - 測量 - 調查等業務共通仕 様書,282p,(社)日本港湾協会,平成 13 年.

2) 保谷忠男:測量叢書, $190 p$, (社) 日本測量協会,1993 年 